\title{
On College English Teacher's Training and Creativity
}

\author{
Shuying An \\ College of Foreign Languages, Changchun University of Science and Technology \\ 7089 Weixing Road, Changchun 130022, China \\ Tel: 86-431-8539-5149Ｅ-mail: cathy7266@sohu.com
}

Received: January 16, 2011 Accepted: February 16, 2011 doi:10.5539/ass.v7n6p199

\begin{abstract}
The main purpose of this paper is to discuss some of the interpretations of the term "teacher", as well as the implications for course content and design, and for the formal qualifications that might be thought appropriate for a "teacher". It also discusses some problems existing in college English teachers themselves in China, and then calls for the urgent need for teacher training. The teacher plays a very important role in ELT (English Language Teaching) and ELL (English Language Learning). Therefore, if we want to apply creativity teaching in ELT, the first and most important thing to do is arouse the teachers' creativity. The teachers themselves should try to improve their quality and use some teaching strategies to better their teaching effect and should also have creative mind to arrange active tasks and activities to arouse students' interests and to cultivate their creativity.
\end{abstract}

Keywords: Teacher training, English teaching, Creativity

\section{Introduction}

We are now at an important stage in educational reform and what is crucial to this reform is the issue of teacher training. Even with perfect syllabuses or text-books, the English teaching shall still achieve little or nothing if the teachers are poorly trained, or untrained. In ELT and ELL, as we know, both teachers and learners are important. Teachers play many important roles in teaching.

\section{Implication of the interpretation of the term "teacher"}

First of all, we talk about some of the interpretations of the term "teacher", as well as the implications for course content and design, and for the formal qualifications that might be thought appropriate for a "teacher". The criteria for a "teacher" are as followed:

(1). A good command of the English language. Of course, the actual definition of "good command" is open to discussion;

(2). A good working knowledge of the language system of English. This should go hand in hand with an awareness of changes taking place in the language, and an awareness of different varieties of the language.

(3). An ability to adapt theoretical knowledge, including from what above to the practical requirements to teaching and learning. The theoretical knowledge should include some awareness of education as a whole: the teacher of English as a foreign language should not only look at TEFL (teaching English as a foreign language) matters alone but also be capable of placing TEFL training in its wider educational context. At the same time, one must emphasize the need to integrate theory with practice. Theoretical knowledge is essential: after all, one must have a rationale for what one is doing. However, it is a rationale, but not a substitute for practice. A good teacher should be able to adapt theories to classroom practice.

(4). The skill of presenting information, and of communicating, orally or in writing, with individuals or groups of learners of varying ages and ablities. This does not come naturally with a university degree: it has to be taught. It is still often assumed that if one knows a language or knows about a language, then one is able to assist others to know it. But we all know of some brilliant professors who are dreadful teachers.

(5). The ability to analyze and evaluate teaching materials according to a learner's needs. Learning materials are never perfect: they need to be individualized to accommodate the teacher's teaching style and the learner's learning style. This means more work for the teachers and complicate matters for the publishers. But if our aim is to help people learn, then we cannot ignore the fact that people learn (and teach) in different ways. 
(6). The ability to analyze learners' needs and to diagnose individual strengths and weaknesses. If we learn indifferent ways, it is up to the teacher to discover what those different styles of cognition are, and to shape teaching rewardingly.

(7). The ability to manage resources for classroom use. The world is full of cassette recorders, sound labs, video-reorders and cameras, tape-slide systems and computers and they are all unused and gathering dust. One reason why they are seldom used or seldom used properly is that the teacher has never been taught how to use them.

(8). The ability and the knowledge necessary for organizing and managing other learning resources such as textbooks and associated materials.

(9). The ability to organize classroom activities at all levels and commensurate with teaching and learning objectives, which in turn presupposes the teacher having overt objectives for learning and teaching.

A person with the above abilities can truly be called a teacher, having reached teacher autonomy". That is to say, the teacher will have reached a threshold from which he or she can develop on his or her own. In turn, the inculcation or fostering of these abilities should condition which components go to make up a teacher-training course. There is no time to develop this now but clearly the structure and content of a teacher-training course should, logically, be dependent on what one expects a teacher to be. Unfortunately, this isn't always the case.

Actually, there are a lot of under-qualified teachers, and there exist some problems in teachers themselves. Firstly, English teachers in China are relatively young with a low-grade diploma and little teaching experience. Because of the expansion of the enrollment of students in universities, teachers are urgently needed. So some university English major students learning English as their specialty without a postgraduate or a doctoral degree become teachers of English after they graduate. This is not the case for teachers in other specialties.

Secondly, English teachers in China lack methodology knowledge. For some young teachers of English, before they stand in front of the students, they have not had a methodology course in their university study and have had no teaching practice at all. They only know the grammar-translation method, for they had been taught with the grammar-translation method since they entered university. For them the grammar-translation method is the most acceptable because they can basically teach English in Chinese, and this inefficient approach is continually reinforced. Quite a number of teachers and senior students want to stay with the grammar-translation method because: first, they think learning grammar in translation is a more academic way of learning English. English is taken as pure knowledge, not a skill. They expect to learn something new about English grammar in every class. If the teacher fails to meet this expectation, the students feel they are not learning anything. We can see the grammar-translation method has taken root in English teaching in China. Secondly, many English teachers feel confident and secure in the traditional method, because they have no competence of controlling the class in a flexible way in quite an open manner. Thirdly, English teachers in China have low motivation for teaching. We often mention learners' motivation for learning. But I think that teachers also have motivation for teaching. Some teachers who like the teaching post dedicate their time and energy to teaching; they are highly motivated, so that they prepare every lesson well and arrange activities and tasks beforehand. But some teachers do not like their teaching post. Being a teacher for them is just like a step up the professional ladder. That is, they want to spend more time in universities, to study to be postgraduates, to get a Ph.D. Sometimes they even want to switch to other subjects. Some of them want to go abroad or get a post in a private or joint venture. Some teachers spend a lot of time on setting up classes for teaching children in order to earn more money. I think that a person's time and energy is limited; if you spend more time and energy in doing other things, then you will have limited time preparing your own lessons.

Fourthly, English teachers in China have heavy burden and have no time to do further study. Because of the increase of the number of students in universities, teachers usually have 14-16 teaching hours a week, sometimes even more. They have to teach big classes of 60-80 students, and they also have to prepare intensive reading, extensive reading, and listening courses. For the young and inexperienced teachers, these tasks will take up so much of their time that they have no more time to refresh themselves, to read theoretical books, to do research on teaching and to carry out their own projects. In other words, they have no more input, just teaching and teaching. This vicious cycle brings bad washback on the whole process of ELT and ELL.

\section{Urgent need for teacher training}

To train more qualified teachers is the key in the whole teaching and learning system. The innovation syllabus and teaching materials have created a big challenge for the teachers. They meet an unprecedented challenge to the traditional methodology of ELT in that the teacher is no longer seen as the sole provider of knowledge and 
the students are no more encouraged to assimilate their teacher's instruction dutifully and to work their way ploddingly through the lines of their textbooks. Teachers are required to transform their views on language teaching, attach more importance to students' ability to use the language, improve their language proficiency, study modern language theory, and change teaching methods. They have to be versatile, e.g., be able to sing, act, and use modern teaching techniques.

At the same time, teachers qualified in the communicative approach are needed badly. 'Qualified teachers' refers to those with both the ability in the four language skills and the knowledge of efficient teaching approaches to help students master the skills (Zhou Yan, 6/2002). You cannot expect a teacher who cannot speak English to teach English in English.

Therefore, qualified English teachers should also have cross-cultural awareness. The methodology of teaching English should be a main course in our teacher programs and this course should be taught by those who have knowledge of the various methodologies available. Let the new teachers be fully prepared before their teaching career begins. And English teachers themselves must take efforts and be willing to change their methods. They must be confident that their students can understand them when they teach in English. Large-scale professional training should be put into modifying the teaching patterns. This can be gradually done through seminars, debates and meetings to observe and emulate.

There are some important things the teachers should know in their teaching training, that is, teaching strategies, teaching style, a teacher's role and classroom behaviors of a successful teacher.

First of all, teachers should know some strategies and use them in a flexible way in the classroom. Actually there are a lot of teaching strategies, in different classes, based on different teachers' individual differences, teachers can choose different strategies. I prefer to use strategy of brainstorming, cooperative learning, demonstration, problem-solving and discussion or debates.

Secondly, a teacher's style is the collection of the many attitudes and behaviors he employs to create the best possible conditions under which learning can take place. It involves the following aspects: motivation, control and discipline, organizing the learning group, teacher's personality, teacher's attitudes and beliefs, etc.

Lastly, Language teaching should be a kind of interactive activity between the teacher and the students. The teacher's role is to help the students with their study. The teacher should pay special attention to the students' needs and interests, and provide and create communicative situations in which students have the chance to use the target language to express them.

To do all this, the teacher not only has to be proficient in the target language but also to bring the students' initiative into full play. The teacher should learn how to organize a big class of over 50 students into groups, pairs, rows, and teams and carry out all kinds of activities. In this way, all the students will be involved in language practice. This will help build up more intimate relations between the teacher and students. And the students will feel free to use the target language to express their ideas and feelings.

In order to make classroom teaching successful, the teacher should try to do the following things: offering a great varieties of activities and short tasks; providing multisensory teaching; conducting lessons mainly, but not exclusively in foreign language; reducing the teacher-student speaking ratio; encouraging students to initiate conversation, ask questions and use conversational gambits; using delayed correction; using expanding techniques; immediately reacting to signals of difficulty.

From what above, it is urgent to improve the creativity of teachers .Nowadays, creativity pedagogy is widely advocated in different levels of teaching systems in China. There are two main points concerning the theme of this teaching idea. One is the concept of creativity pedagogy: everyone has creative potential; teachers keep the student's curiosity well; success can promote more success. The other is the principles of creativity pedagogy: paying close attention to life; bringing happiness back to students' childhood; teaching students in accordance with their aptitude; activity is the life and sole of creativity pedagogy; setting up free, democratic, relaxing and harmonious surroundings.

In order to attain creativity teaching, the first and most important thing is to train the teachers' creativity.

Today's students live in an ever changing technologically based world where the parameters of knowledge are redefining themselves almost daily. As a result, teachers now find themselves competing for student's time and attention. The allure of computers and video games is often overwhelming for young minds and many educators find themselves losing an ever escalating battle for their students' interest. As a result, teachers are being called upon to develop more creative approaches in order to teach this new generation of students. The learning process has changed and teachers have been challenged to change as well, or be left behind. This change must involve 
new and creative approaches to everyday classroom instruction.

Teachers who wish to be more creative must first express a willingness to change their approach to teaching. The need for change can best be understood and more readily accomplished by understanding that education by and large lies in 'what' educations do in the classroom. If teachers change 'what' they do, they change the outcome of the learning process.

Firstly, they should examine the specific subject materials they are currently teaching and make informed decision on what to include and what to exclude from their daily lesson plans. Teachers must be willing to eliminate older material that is no longer relevant and that must give way to more current more important materials.

Secondly, they must be willing to utilize different methodologies, strategies, and approaches to instruction, and they must also be willing to change their assessment tools and evaluation criteria. However, they will do so only if they have a firm understanding and mastery of these techniques.

This mastery can be acquired either through training or by observation of other teachers who effectively utilized such strategies. By acquiring such experience, teachers establish foundations for success within their classroom. With proper training teachers can open the door to a whole new world of instruction, a world where they can excite, challenge, and empower students. Simply by effectively changing modes of instruction, teachers can transform a classroom from a four walled room filled with educational hopes into an environment that arouses curiosity, beckons to learn, and embraces creativity.

\section{Conclusion}

From the above mentioned, teachers play a very important role in ELT and ELL, so teacher themselves should try to improve their quality and use some teaching strategies to better their teaching effect. Teachers themselves should have creative mind to arrange active tasks and activities to arouse students' interests and to cultivate their creativity. By doing this, our ELT and ELL will make great progress in the future.

\section{References}

Brumfit, C. J. (1979). The Communicative Approach to Language Teaching. Oxford: Oxford University Press.

Gattegno, C. (1976). The Common Sense of Teaching Foreign Languages. New York: Educational Solutions.

Kehoe, M. (1971). Applied Linguistics: A Survey for Language Teachers. New York: Macmillan.

Widdowson, H.G. (1978). Teaching Language as Communication. Oxford: Oxford University Press.

Widdowson, H.G. (1987). The Role of Teacher and Learner. ELT Journal, Vol.41, No.2:83-8.

Widdowson, H.G. (1990). Aspect of Language Teaching. Oxford: Oxford University Press. 